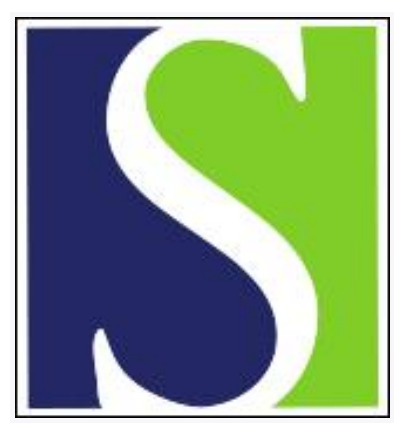

Scand J Work Environ Health 1986;12(5):504-511

https://doi.org/10.5271/sjweh.2107

Issue date: Oct 1986

A tracer pulse method for the assessment of airflow patterns in a particleboard mill.

by Niemela $\mathrm{R}$

This article in PubMed: www.ncbi.nlm.nih.gov/pubmed/3787222

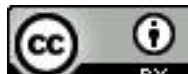




\title{
A tracer pulse method for the assessment of airflow patterns in a particleboard mill
}

\author{
by Raimo Niemelä, $\mathrm{PhL}^{1}$
}

\begin{abstract}
NIEMELÄ R. A tracer pulse method for the assessment of airflow patterns in a particleboard mill. Scand $J$ Work Environ Health 12 (1986) 504-511. A tracer pulse method was used to investigate the spread of airborne formaldehyde from its source into the surrounding air and the distribution of the air supply in a particleboard mill. The contaminant flow was labeled with sulfur hexafluoride, and the supply of outdoor air with nitrous oxide. The pulse responses of the injected tracer gases were interpreted in terms of the age concept. The result of improvements in the ventilation system was studied through measurements of the formaldehyde concentration and with tracer gas tests. It was found that the approach used in this paper is applicable to charting airflow patterns in a complex industrial environment.
\end{abstract}

Key terms: formaldehyde, industrial ventilation, residence time.

Airborne formaldehyde is a significant health problem in the particleboard industry (5). Particleboard is fabricated by the simultaneous compression and heating of wood chips, usually with urea-formaldehyde resins as bonding agents. The automated production line contains the following main stages: blending, forming, hot pressing, and finishing. Formaldehyde vapor is emitted at all stages, especially during the hot pressing. Even the cooled board contains uncombined formaldehyde, which gradually diffuses into the surrounding air.

Local exhaust ventilation is the most recommended engineering method for controlling air contaminants in factories. However, in particleboard mills, the installation of exhaust hoods over all sources of formaldehyde vapor is a difficult task because of the many wide sources and the use of conveyor belts in the production lines. Often the local exhaust systems do not operate at $100 \%$ efficiency, especially when hot surfaces induce strong thermal currents. Therefore the role of general ventilation in reducing occupational exposure to toxic vapors is emphasized. Knowledge of the distribution of the air supply, airflow patterns, and the spread of contaminated air are of vital importance in the design of an effective ventilation system.

Airflow patterns in large industrial premises such as particleboard mills are very complex. Before data on the behavior of both fresh airflows and contaminant flows can be obtained, the flow patterns in the area must first be charted. The tracer gas technique seems to be a very useful method for field studies of air movements in complex work environments (6). In this method, a small amount of tracer is added to the flow under investigation, and responses to the tracer are

\footnotetext{
1 Institute of Occupational Health, Helsinki, Finland.
}

Reprint requests to: Mr R Niemelä, Institute of Occupational Health, Department of Industrial Hygiene, and Toxicology, Laajaniityntie 1, SF-01620 Vantaa, Finland. monitored at the various points of interest. Interpretation of the response curves through age analysis has been successfully used in chemical reaction engineering and in biophysics. The residence time theory has been utilized to improve the yield of chemical reactors (8). In biophysics, it is common practice to measure the length of time a given fluid remains in a certain part of the human circulation system (2). While age analysis in ventilation studies has been used primarily in the laboratory, it has also been used in studies of office rooms $(7,12,13,14)$. The age concept has also been applied to the charting of the distribution of the air supply in large industrial premises (9).

The purpose of this investigation was to study the application of the tracer pulse method to the charting of both the dispersion of formaldehyde vapor from its source into the air and the distribution of the air supply. The formaldehyde-contaminated flow was labeled with sulfur hexafluoride, and the fresh airflow with nitrous oxide. The tracer gas tests and the measurements of formaldehyde concentration were carried out both before and after changes were made in the ventilation system. Data derived from the tracer tests were compared to the actual concentrations of formaldehyde. The results indicated that this method can be successfully applied to charting even very complex airflow patterns in work environments.

\section{Materials and methods}

\section{Theoretical basis}

Consider any continuous airflow system, eg, in a room with one or more flow entrances and exits. Suppose that the flow rate $\mathrm{Q}$ is constant, and the room volume is $\mathrm{V}$. The nominal time constant, $\tau_{\mathrm{n}}$, of the system is then $\mathrm{V} / \mathrm{Q}$. The fluid elements, molecules or particles, enter the room, remain in it for some period of time and then leave. Particles have zero age when they first 
enter and acquire age at a rate equal to time spent within the room. The age of a fluid element at its exit is called the residence time. For the fluid elements leaving the room there is a cumulative distribution, $F(t)$, which gives the fraction of those fluid elements younger than $t . F(t)$ is defined over $(0, \infty)$ so that $F(0)=0$ and $F(\infty)=1$.

The corresponding frequency or density distribution, $f(t)$, is then derived as follows:

$$
f(t)=\frac{d F}{d t} \text { or } F(t)=\int_{o}^{t} f(t) d t .
$$

equation 1

The frequency function, $f(t)$, gives a nonnegative function over $(0, \infty)$.

In addition to the elements leaving the room, the fluid elements within the room, ie, the fresh air molecules entering the room from the supply ducts, and contaminants released within the room are also of interest. The following three different populations of fluid elements can be distinguished: a total internal population consisting of all fluid elements within the room, a local internal population at an arbitrary point within the room, and an external population consisting of fluid elements leaving the room. Each population may be characterized by their age distribution.

The moments of the age distributions are defined in the usual way for nonnegative random variables (3). The moments are derived with the formula:

$$
\mu_{n}=\int_{0}^{\infty} t^{n} f(t) d t
$$

equation 2

where $n=0,1,2, \ldots$.

The zeroth moment is equal to one as a consequence of the requirement that $F(\infty)=1$. The first moment, $\mu_{1}$, is the centroid or the mean of the distribution. The variance, $\delta^{2}$, is expressed as follows (3):

$$
\delta^{2}=\mu_{2}-(\tau)^{2},
$$

equation 3

where the first moment, $\mu_{1}$, is denoted by $\tau$. The standard deviation, $\delta$, is obtained as a positive root of the variance.

The age distribution and corresponding frequency distributions may be determined experimentally with stimulus-response techniques. The stimulus is a tracer signal input at the supply duct or at the source of a contaminant flow. The responses are the concentration values measured either at given points within the room or at the flow exit, depending on the situation. In principle any type of tracer signal may be used. However, the most common signals in ventilation studies are the pulse, step-up, and step-down (11).

In the pulse method, the tracer gas is introduced in one short pulse either into the intake air duct or at a given point within the room. The idealized impulse input can be mathematically represented by an impulse function (4). The impulse response curve represents the density function of the corresponding age distribution. In the step-up method the tracer gas is injected at a constant flow rate. The recorded response represents the cumulative distribution. In the step-down method, the recorded concentration curve gives the complementary cumulative age distribution $1-F(t)$.

The usual practice in experiments in which the pulse method is used is to inject a small quantity of tracer rapidly and then monitor its concentration, $C(t)$, as a function of time at the point of interest. $C(t)$ is then normalized to give frequency distribution $f(t)$ with $\mu_{\mathrm{o}}=1$ :

$$
f(t)=\frac{C(t)}{\int_{0}^{\infty} C(t) d t} .
$$

equation 4

The moments and the variance may then be calculated from equations 2 and 3 . The calculated moments will be heavily dependent on experimental data taken at high values of $t$, ie, at very low concentrations. For this reason Nauman (8) recommends using no moments higher than the second.

If the tracer concentrations are measured as discrete values, the discrete age distribution is obtained. The moments and the variance are correspondingly calculated as follows:

$$
\mu_{n}=\frac{\sum_{i}^{k} t_{i}^{n} C_{i}(t)}{\sum_{1}^{k} C_{i}(t)},
$$
equation 5

where $n=0,1,2 \ldots$, and

$$
\delta^{2}=\frac{\sum_{1}^{k} \mathrm{t}_{i}^{2} C_{i}(t)}{\sum_{1}^{k} C_{i}(t)}-(\tau)^{2},
$$

equation 6

where $k$ is the number of samples taken.

Other parameters describing flow behavior in the room may also be determined from the pulse response curves. The dosage, $D(t)$, is the time integral of the concentration up to time $t(13)$ :

$$
D(t)=\int_{0}^{t} C(t) d t .
$$

equation 7

As $t \rightarrow \infty, D$ becomes the total dosage (or area under the concentration curve). The maximum concentration and the time instant, when this maximum is achieved, can be determined directly from the response curve.

\section{Description of the mill}

The production capacity of the particleboard mill under investigation was $150 \mathrm{~m}^{3} / \mathrm{d}$. The mill is run in three shifts, with $10-15$ persons continuously present in the production hall. The hot press is operated continuously. The layout and a cross-section of the mill are shown in figure 1.

During the first measurements, the supplied air was introduced primarily through air supply system $S_{1}$. 

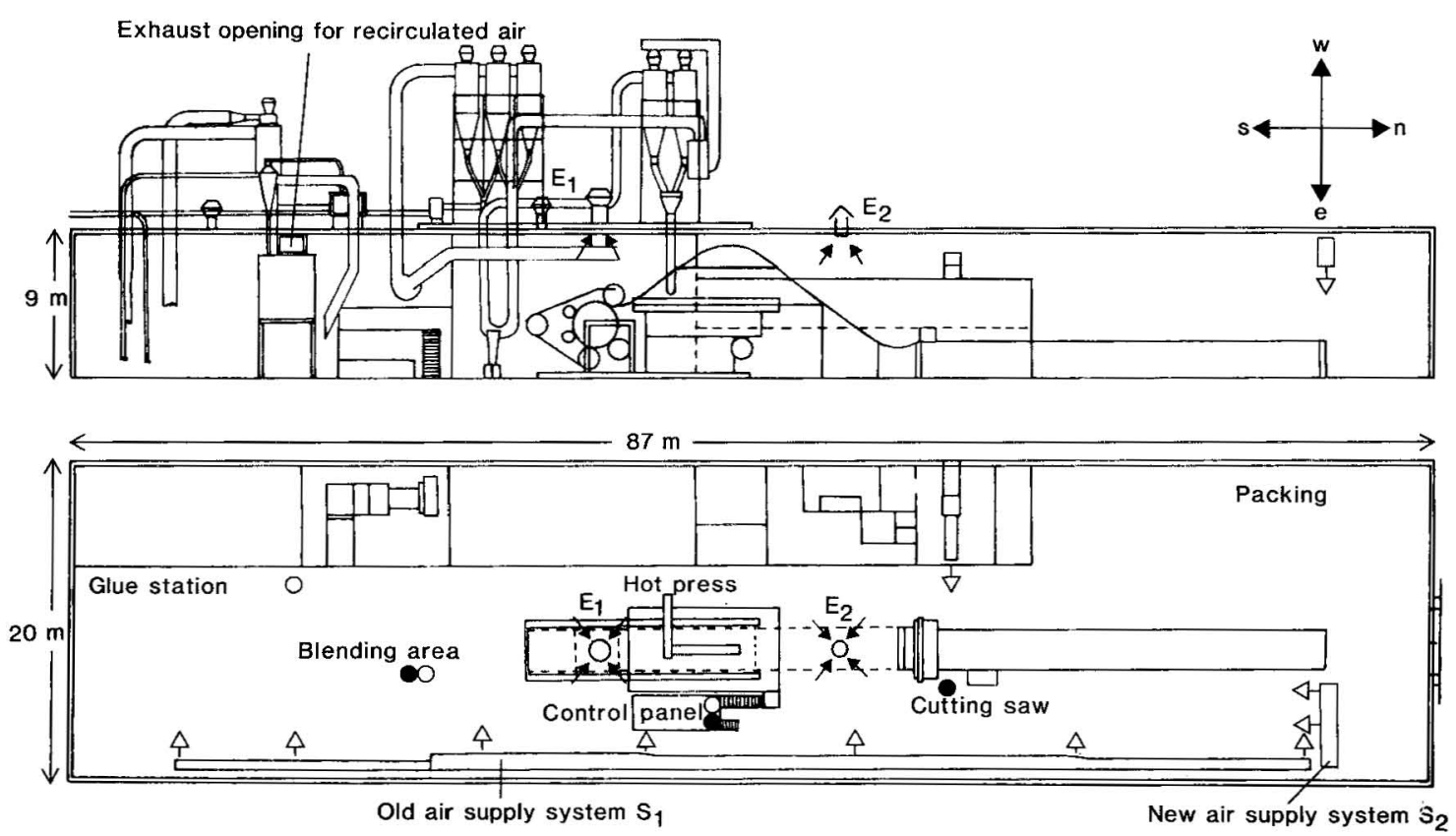

Figure 1. Layout and cross-section of the particleboard mill. $(\mathrm{O}=$ sampling sites before the changes in the ventilation system, $\bullet=$ sampling sites after the changes in the ventilation system, $\leftarrow=$ supply air, $\leftarrow=$ exhaust air)

(See figure 1.) The supplied airflow included $30 \%$ recirculation air, which was exhausted near the ceiling above the blending area. The supplied air was blown towards the workzone around the production line from grills located at a height of $2.1 \mathrm{~m}$ on the long eastern wall. Roof exhaust fans $E_{1}$ and $E_{2}$ (in figure 1) were used to control the formaldehyde to some extent. The exhaust flow rate of $E_{1}$ was about $30 \%$ of the total exhaust flow rate, and the flow rate of $E_{2}$ about $20 \%$. The rest of the exhaust air was sucked from the saws and the lower part of the press. There was no hood above the hot press. The mechanical airflow rates were strongly unbalanced because the fresh outdoor airflow rate was only about $50 \%$ of the exhaust flow rate. The air exchange rate based on exhaust flow measurements was $8.5 \mathrm{~h}^{-1}$.

After changes in the ventilation arrangements a second, extended set of data was collected. The following changes were done to improve ventilation for contaminant control. The upper part of the hot press was enclosed on three sides with a hood extending down $5 \mathrm{~m}$ from the ceiling. The side of the hood opening towards the cutting saw was not enclosed, as enclosure would have interfered with movement of the conveyor. The use of recirculated air ceased. A new fresh air fan $\mathrm{S}_{2}$ (in figure 1) was installed in the northern end of the plant near the ceiling. It doubled the fresh airflow rate. After these changes the mechanical exhaust flow rates and the fresh airflow rates were approximately in balance. The measured air exchange rate was then $7.7 \mathrm{~h}^{-1}$.

\section{Experimental procedure}

Two tracer gases were used in this study. Contaminant dispersion from the hot press was marked with sulfur hexafluoride $\left(\mathrm{SF}_{6}\right)$. The fresh air supply was labeled with nitrous oxide $\left(\mathrm{N}_{2} \mathrm{O}\right)$ in the tests carried out after the changes in the ventilation systems.

Sulfur hexafluoride was injected via perforated plastic tubing into the hot press, which was the main source of formaldehyde vapor. The volume of the sulfur hexafluoride pulse was 1.01 , and the injection time $60 \mathrm{~s}$. The release rate of the gas was controlled by a rotameter with a millimeter scale for standard air. The volume flow values were converted for the gas according to the manufacturer's calibration charts. The accuracy of the sulfur hexafluoride volume released was estimated at $\pm 10 \%$. After the sulfur hexafluoride pulse five air samples of 1 -min duration were collected every second minute at two or five sampling sites. The air was collected in laminated plastic bags with the use of sampling pumps at a flow rate of $1.0 \mathrm{l} / \mathrm{min}$. The samples were analyzed the same day in the mill with a portable gas chromatograph (AID model 621, Analytical Instrument Development, Inc, United States). Because the samples taken only covered the time up to $10 \mathrm{~min}$ after the sulfur hexafluoride release, analytical extrapolation was used beyond this period. An exponential tail was fitted to the experimental values. In the extrapolation, $-\mathrm{t} / \tau_{n}$ was used as an exponent, ie, it was assumed that the decay of concentration was governed by the nominal time constant $\tau_{n}$. 
The volume of the nitrous oxide pulses released in the fresh air was usually $50 \mathrm{l}$. One test was carried out with a pulse volume of 1001 . The injection time was $60 \mathrm{~s}$ in each test. Nitrous oxide was injected into the fresh airflow before the fan. This arrangement guaranteed a homogeneous tracer-air mixture. The discharge flow rate was controlled by a rotameter calibrated for nitrous oxide.

The concentration of nitrous oxide was measured with a portable field measurement unit utilizing two infrared analyzers (Miran 1A, Foxboro Analytical) (10). The first analyzer continuously sucked sample air from the workzone, and the second from the upper part of the room (at a height of $7.5 \mathrm{~m}$ ). The infrared analyzers were calibrated against each other with a closed loop calibration system.

The airborne formaldehyde concentration was measured according to a standard method comprising sampling into a dilute sodium bisulfite solution and spectrophotometric determination after evaporation of the sample solution and the addition of the colorforming reagent chromotropic acid (15). The typical sampling rate was $1 \mathrm{l} / \mathrm{min}$, and the sampling time about $1 \mathrm{~h}$. In addition to this method, the formaldehyde concentration was continuously monitored with a 12-channel infrared analyzer (Miran multipoint ambient air analyzer with Miran 1A measuring head, Foxboro Analytical) to record temporal fluctuations.

The airflows in the intake and exhaust ducts were measured with a standard Pitot tube and an electrical micromanometer (Furness Control) according to the multipoint traversing method (1). Air velocities at the intake and exhaust air openings were measured with a vane anemometer (Airflow Developments).

\section{Results}

The measurements taken before the changes in the ventilation system were directed at charting the spread of formaldehyde vapor from the hot press to the blend- ing area and towards the intake opening for recirculated air. The results of the repeated tracer gas tests (numbers $1-3$ ) are presented in table 1 . Typical discrete concentration values of the sulfur hexafluoride responses (test 3 ) are shown in figure 2.

The formaldehyde concentrations observed at the sampling sites of sulfur hexafluoride are also given in table 1 . The concentration of formaldehyde at the cutting saw at the height of $1.5 \mathrm{~m}$ was $2.4 \mathrm{ppm}$.

After the changes in the ventilation system, extended measurements were made to chart the dispersion of formaldehyde vapor and the distribution of the fresh air supply. The sulfur hexafluoride samples were collected at three sites in the workzone (at the control panel, in the blending area, and at the cutting saw) and in the exhaust air of two roof fans. The results of the repeated sulfur hexafluoride tests (numbers 4-6), as well as the corresponding formaldehyde concentrations, are presented in table 2 .

Distribution of the fresh air supplied by both the old and new air supply systems was charted in tests with nitrous oxide. The typical concentration responses of nitrous oxide are shown in figures 3 and 4 . The local mean age of the fresh air and other parameters obtained from the nitrous oxide responses are presented in table 3 . The formaldehyde concentrations detected at the sampling sites for nitrous oxide are also given in table 3 .

\section{Discussion}

The results of the tracer tests carried out before the changes were made in the ventilation system (table 1) indicate that the local mean residence time and the time instant for the maximum sulfur hexafluoride concentration, measured in the recirculation opening and above the blending area, were clearly shorter than the corresponding values in the workzone. The maximum concentration of sulfur hexafluoride and the total

Table. 1. Results of the sulfur hexafluoride tests before improvements in the ventilation system - Release in the hot press, nominal time constant $7.1 \mathrm{~min}$. ( $\tau_{\mathrm{c}}=$ local mean age of the contaminant, $\delta=$ standard deviation, $\mathrm{C}_{\max }=$ maximum sulfur hexafluoride concentration, $t_{\max }=$ time instant for the maximum sulfur hexafluoride concentration, $D_{\text {tot }}=$ total dosage, $C_{H C H O}=$ concentration of formaldehyde)

\begin{tabular}{|c|c|c|c|c|c|c|}
\hline $\begin{array}{l}\text { Sampling } \\
\text { site }\end{array}$ & $\underset{(\mathrm{min})}{\tau_{c}}$ & $\begin{array}{c}\delta \\
(\min )\end{array}$ & $\begin{array}{l}\mathrm{C}_{\max } \\
(\mathrm{ppb})\end{array}$ & $\underset{(\min )}{t_{\max }}$ & $\begin{array}{c}D_{\text {tot }} \\
(p p b \cdot \min )\end{array}$ & $\begin{array}{l}\mathrm{C}_{\mathrm{HCHO}} \\
(\mathrm{ppm})\end{array}$ \\
\hline \multicolumn{7}{|l|}{ Control panel } \\
\hline $\begin{array}{l}\text { Test } 1 \\
\text { Test } 2 \\
\text { Test } 3\end{array}$ & $\begin{array}{l}10.2 \\
10.7 \\
10.9\end{array}$ & $\begin{array}{l}5.7 \\
5.7 \\
5.5\end{array}$ & $\begin{array}{l}65 \\
62 \\
49\end{array}$ & $\begin{array}{l}8 \\
6 \\
8\end{array}$ & $\begin{array}{l}395 \\
390 \\
245\end{array}$ & $\begin{array}{l}2.7 \\
2.7 \\
2.7\end{array}$ \\
\hline \multicolumn{7}{|l|}{ Blending area } \\
\hline $\begin{array}{l}\text { Test } 3 \text {, height } 1.5 \mathrm{~m} \\
\text { Test } 3 \text {, height } 4 \mathrm{~m}\end{array}$ & $\begin{array}{r}10.2 \\
8.3\end{array}$ & $\begin{array}{l}5.7 \\
5.5\end{array}$ & $\begin{array}{r}89 \\
183\end{array}$ & $\begin{array}{l}8 \\
4\end{array}$ & $\begin{array}{l}490 \\
810\end{array}$ & $\begin{array}{l}0.8 \\
\cdots\end{array}$ \\
\hline \multicolumn{7}{|l|}{ Recirculation opening } \\
\hline $\begin{array}{l}\text { Test } 1 \\
\text { Test } 2 \\
\text { Test } 3\end{array}$ & $\begin{array}{l}7.5 \\
6.1 \\
6.0\end{array}$ & $\begin{array}{l}5.3 \\
5.4 \\
5.1\end{array}$ & $\begin{array}{l}228 \\
465 \\
435\end{array}$ & $\begin{array}{l}4 \\
2 \\
2\end{array}$ & $\begin{array}{r}740 \\
1160 \\
1220\end{array}$ & $\begin{array}{l}2.0 \\
2.0 \\
2.0\end{array}$ \\
\hline
\end{tabular}



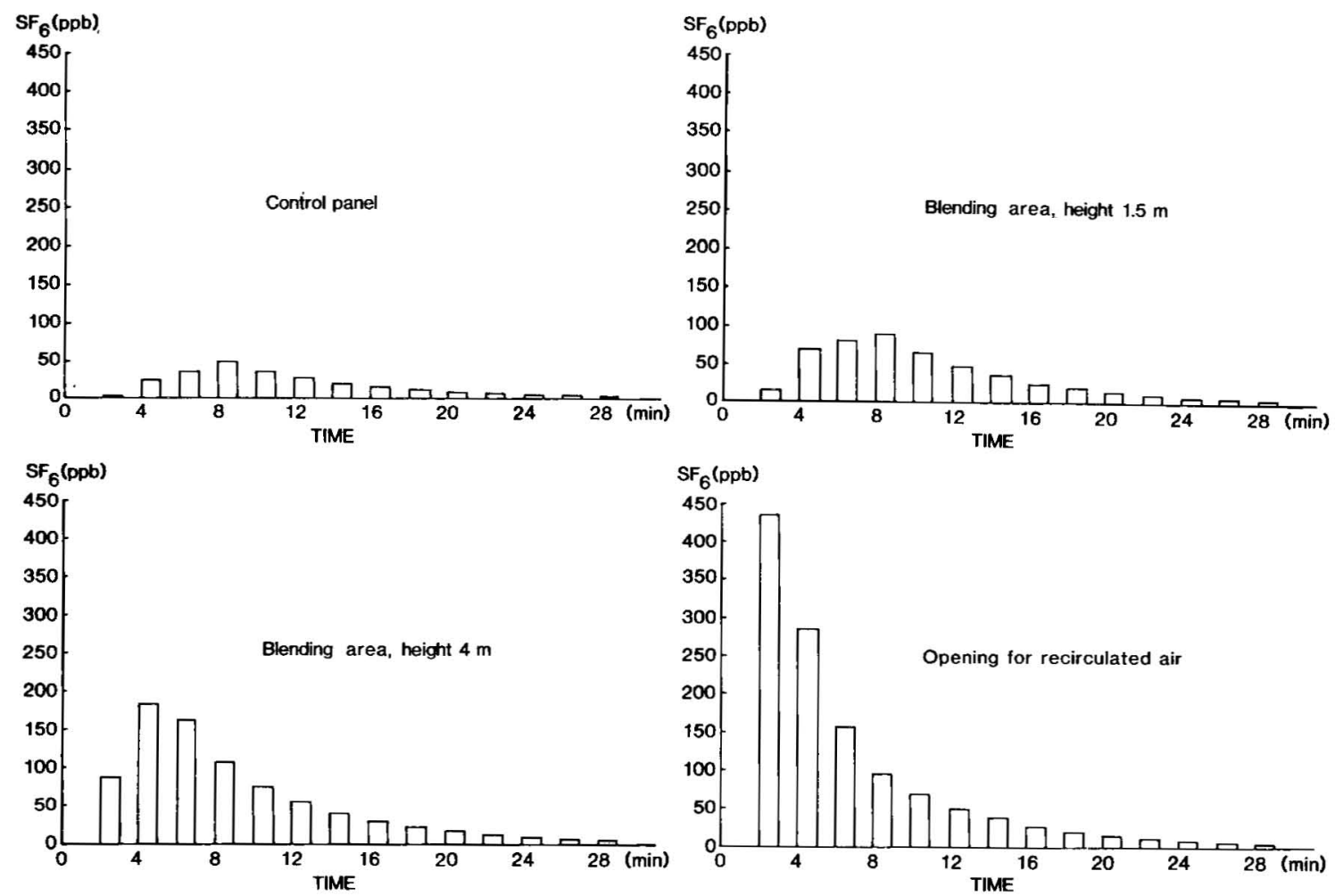

Figure 2. Examples of concentration responses from a sulfur hexafluoride $\left(\mathrm{SF}_{6}\right)$ pulse injection in the hot press (test 3 in table 1).

Table 2. Results of the sulfur hexafluoride tests after improvements in the ventilation system - Release in the hot press, nominal time constant $7.8 \mathrm{~min} .\left(_{\mathrm{c}}=\right.$ local mean age of the contaminant, $\delta=$ standard deviation, $C_{\max }=$ maximum sulfur hexafluoride concentration, $t_{\max }=$ time instant for the maximum sulfur hexafluoride concentration, $D_{\text {tot }}=$ total dosage, $\mathrm{C}_{\mathrm{HCHO}}$ $=$ formaldehyde concentration)

\begin{tabular}{|c|c|c|c|c|c|c|}
\hline $\begin{array}{l}\text { Sampling } \\
\text { site }\end{array}$ & $\begin{array}{c}\tau_{\mathrm{c}} \\
(\mathrm{min})\end{array}$ & $\begin{array}{c}\delta \\
(\min )\end{array}$ & $\begin{array}{l}\mathrm{C}_{\max } \\
(\mathrm{ppb})\end{array}$ & $\begin{array}{c}t_{\max } \\
(\min )\end{array}$ & $\begin{array}{c}D_{\text {tot }} \\
(\mathrm{ppb} \cdot \mathrm{min})\end{array}$ & $\begin{array}{l}\mathrm{C}_{\mathrm{HCHO}} \\
(\mathrm{ppm})\end{array}$ \\
\hline \multicolumn{7}{|c|}{ Control panel $1.5 \mathrm{~m}$} \\
\hline $\begin{array}{l}\text { Test } 4 \\
\text { Test } 5 \\
\text { Test } 6\end{array}$ & $\begin{array}{r}10.1 \\
8.0 \\
8.9\end{array}$ & $\begin{array}{l}6.1 \\
5.8 \\
6.2\end{array}$ & $\begin{array}{r}14.1 \\
18.5 \\
6.2\end{array}$ & $\begin{array}{l}5 \\
3 \\
3\end{array}$ & $\begin{array}{l}80 \\
60 \\
25\end{array}$ & $\begin{array}{l}1.00 \\
1.10 \\
0.80\end{array}$ \\
\hline \multicolumn{7}{|c|}{ Blending area $1.5 \mathrm{~m}$} \\
\hline $\begin{array}{l}\text { Test } 5 \\
\text { Test } 6\end{array}$ & $\begin{array}{l}7.4 \\
9.8\end{array}$ & $\begin{array}{l}6.3 \\
6.2\end{array}$ & $\begin{array}{l}6.2 \\
2.4\end{array}$ & $\begin{array}{l}1 \\
5\end{array}$ & $\begin{array}{l}20 \\
10\end{array}$ & $\begin{array}{l}0.4 \\
0.3\end{array}$ \\
\hline \multicolumn{7}{|c|}{ Cutting saw $1.5 \mathrm{~m}$} \\
\hline $\begin{array}{l}\text { Test } 4 \\
\text { Test } 5\end{array}$ & $\begin{array}{l}11.9 \\
11.8\end{array}$ & $\begin{array}{l}5.9 \\
5.8\end{array}$ & $\begin{array}{r}11.5 \\
3.2\end{array}$ & $\begin{array}{l}9 \\
7\end{array}$ & $\begin{array}{l}65 \\
15\end{array}$ & $\begin{array}{l}0.8 \\
0.7\end{array}$ \\
\hline \multicolumn{7}{|c|}{ Roof exhaust fan $E_{1}$} \\
\hline $\begin{array}{l}\text { Test } 4 \\
\text { Test } 5 \\
\text { Test } 6\end{array}$ & $\begin{array}{l}2.5 \\
2.6 \\
2.5\end{array}$ & $\begin{array}{l}3.1 \\
4.1 \\
3.2\end{array}$ & $\begin{array}{l}300 \\
295 \\
205\end{array}$ & $\begin{array}{l}1 \\
1 \\
1\end{array}$ & $\begin{array}{l}505 \\
370 \\
350\end{array}$ & $\begin{array}{l}26.0 \\
11.0\end{array}$ \\
\hline \multicolumn{7}{|c|}{ Roof exhaust fan $E_{2}$} \\
\hline $\begin{array}{l}\text { Test } 4 \\
\text { Test } 5 \\
\text { Test } 6\end{array}$ & $\begin{array}{l}2.3 \\
2.5 \\
2.5\end{array}$ & $\begin{array}{l}3.3 \\
4.1 \\
3.0\end{array}$ & $\begin{array}{l}260 \\
260 \\
310\end{array}$ & $\begin{array}{l}1 \\
1 \\
1\end{array}$ & $\begin{array}{l}375 \\
325 \\
555\end{array}$ & $\begin{array}{l}2.7 \\
5.0\end{array}$ \\
\hline
\end{tabular}

dosage at these sites were greater than those in the sampling sites in the workzone.

These results indicate that formaldehyde vapors simulated with a sulfur hexafluoride pulse were rapidly spread towards the recirculation air opening and the upper part of the mill, above the blending area. There- fore the tracer tests showed clearly that the location of the recircultation opening was very unsuitable. The actual concentration of formaldehyde in the recirculation air was $2.0 \mathrm{ppm}$, whereas the concentration of formaldehyde at the control panel was higher, $2.7 \mathrm{ppm}$. Therefore other sources of formaldehyde, as formalde- 


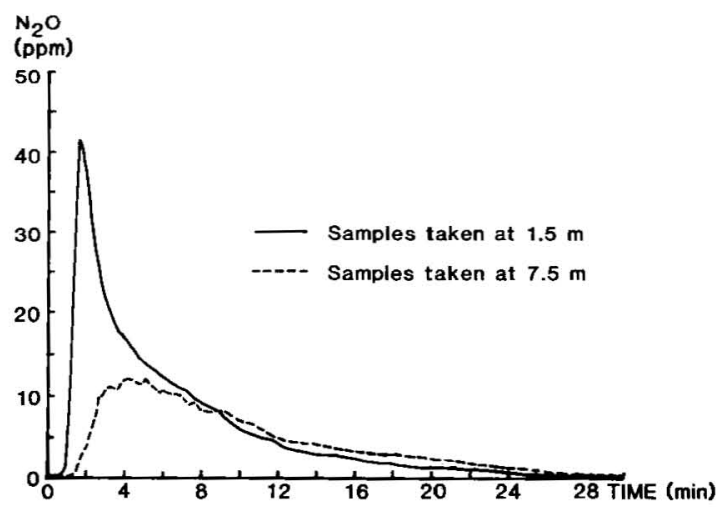

Figure 3. Examples of concentration responses at the cutting saw from a nitrous oxide $\left(\mathrm{N}_{2} \mathrm{O}\right)$ pulse injection in the new air supply system, $\mathrm{S}_{2}$ (test 8 in table 3 ).

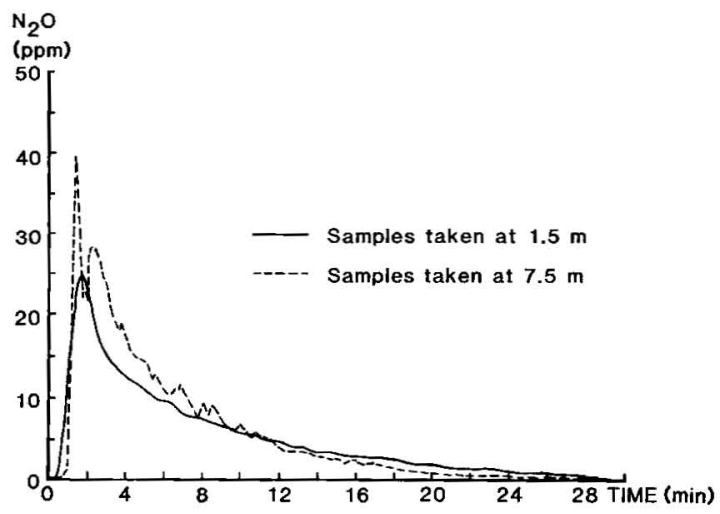

Figure 4. Examples of concentration responses in the blending area from a nitrous oxide $\left(\mathrm{N}_{2} \mathrm{O}\right)$ pulse injection in the old supply air system, $\mathrm{S}_{1}$ (test 11 in table 3 ).

Table 3. Results of the nitrous oxide tests after improvements in the ventilaton system - Nominal time constant 7.8 min. $\left(\tau_{\mathrm{a}}=\right.$ local mean age of the supplied air, $\delta=$ standard deviation, $\mathrm{C}_{\max }=$ maximum nitrous oxide concentration $\mathrm{t}_{\mathrm{max}}=$ time instant for the maximum nitrous oxide concentration, $D_{\text {tot }}=$ total dosage, $C_{\mathrm{HCHO}}=$ formaldehyde concentration)

\begin{tabular}{|c|c|c|c|c|c|c|}
\hline $\begin{array}{l}\text { Sampling } \\
\text { site }\end{array}$ & $\begin{array}{c}\tau_{\mathrm{a}} \\
(\mathrm{min})\end{array}$ & $\begin{array}{c}\delta \\
(\mathrm{min})\end{array}$ & $\begin{array}{c}\mathrm{C}_{\max } \\
(\mathrm{ppm})\end{array}$ & $\begin{array}{c}t_{\max } \\
(\min )\end{array}$ & $\begin{array}{c}D_{\text {tot }} \\
(\mathrm{ppm} \cdot \min )\end{array}$ & $\begin{array}{l}\mathrm{C}_{\mathrm{HCHO}} \\
(\mathrm{ppm})\end{array}$ \\
\hline \multicolumn{7}{|c|}{ Test 7 (100 l released from new supply fan $\left.S_{2}\right)$} \\
\hline $\begin{array}{l}\text { Control panel, } 1.5 \mathrm{~m} \\
\text { Control panel, } 7.5 \mathrm{~m}\end{array}$ & $\begin{array}{l}6.4 \\
6.8\end{array}$ & $\begin{array}{l}4.7 \\
4.6\end{array}$ & $\begin{array}{l}69.3 \\
34.1\end{array}$ & $\begin{array}{l}3.1 \\
3.4\end{array}$ & $\begin{array}{l}350 \\
230\end{array}$ & $\begin{array}{l}1.1 \\
1.3\end{array}$ \\
\hline \multicolumn{7}{|c|}{ Test 8 (50 I released from new supply fan $S_{2}$ ) } \\
\hline $\begin{array}{l}\text { Cutting saw, } 1.5 \mathrm{~m} \\
\text { Cutting saw, } \\
7.5 \mathrm{~m}\end{array}$ & $\begin{array}{l}6.3 \\
9.1\end{array}$ & $\begin{array}{l}5.4 \\
6.2\end{array}$ & $\begin{array}{l}41.1 \\
12.0\end{array}$ & $\begin{array}{l}1.7 \\
4.3\end{array}$ & $\begin{array}{l}225 \\
155\end{array}$ & $\begin{array}{l}0.8 \\
1.5\end{array}$ \\
\hline \multicolumn{7}{|c|}{ Test 9 (50 I released from old supply duct $\left.S_{1}\right)$} \\
\hline $\begin{array}{l}\text { Cutting saw, } 1.5 \mathrm{~m} \\
\text { Cutting saw, } 7.5 \mathrm{~m}\end{array}$ & $\begin{array}{l}6.5 \\
6.0\end{array}$ & $\begin{array}{l}4.2 \\
4.2\end{array}$ & $\begin{array}{r}7.9 \\
13.0\end{array}$ & $\begin{array}{l}2.3 \\
2.6\end{array}$ & $\begin{array}{r}70 \\
105\end{array}$ & $\begin{array}{l}0.8 \\
1.5\end{array}$ \\
\hline \multicolumn{7}{|c|}{ Test 10 (50 l released from old supply duct $\left.S_{l}\right)$} \\
\hline $\begin{array}{l}\text { Cutting saw, } 1.5 \mathrm{~m} \\
\text { Cutting saw, } 7.5 \mathrm{~m}\end{array}$ & $\begin{array}{l}6.5 \\
5.4\end{array}$ & $\begin{array}{l}4.2 \\
4.9\end{array}$ & $\begin{array}{r}7.0 \\
31.6\end{array}$ & $\begin{array}{l}2.9 \\
2.8\end{array}$ & $\begin{array}{l}60 \\
90\end{array}$ & $\begin{array}{l}0.8 \\
1.5\end{array}$ \\
\hline \multicolumn{7}{|c|}{ Test 11 (50 I released from old supply duct $\left.S_{1}\right)$} \\
\hline $\begin{array}{l}\text { Blending area, } 1.5 \mathrm{~m} \\
\text { Blending area, } 7.5 \mathrm{~m}\end{array}$ & $\begin{array}{l}3.7 \\
5.4\end{array}$ & $\begin{array}{l}5.8 \\
4.1\end{array}$ & $\begin{array}{l}24.6 \\
39.3\end{array}$ & $\begin{array}{l}1.7 \\
1.4\end{array}$ & $\begin{array}{l}170 \\
205\end{array}$ & $\begin{array}{l}0.4 \\
0.3\end{array}$ \\
\hline
\end{tabular}

hyde flow labeled with sulfur hexafluoride, contributed to the concentration of formaldehyde at the control panel.

The repeatability of the sulfur hexafluoride tests at the control panel seemed to be rather good. Only the total dosage in test 3 was smaller than that in the other two tests. There was also good agreement between the results of test 2 and test 3 at the recirculation opening, whereas the values from test 1 showed that sulfur hexafluoride spread more slowly in that direction. This result indicates slight instability in flow patterns between the hot press and the recirculation opening.

As a consequence of changes in the ventilation system, the concentration of formaldehyde was reduced more than $50 \%$ at the sampling sites in the workzone. The measured exhaust airflows were slightly smaller than before the improvements, resulting in a higher nominal time constant of $7.8 \mathrm{~min}$. This finding was a bit surprising, since the amount of the mechanical air supply flows was substantially increased. The discrepancy was probably due to inaccuracies in the determination of exhaust airflows. In particular, the velocity fields in the output openings of the two large roof fans, $E_{1}$ and $E_{2}$, were distorted and caused measurement errors.

In a comparison of the results of the sulfur hexafluoride tests before and after the changes, it can be seen that these changes reduced the total dosage and the maximum concentration of sulfur hexafluoride by more than $70 \%$ at the control panel and in the blending area. On the other hand, the local mean residence time measured at these sites was not so much reduced. The values in table 2 show that the dispersion of formaldehyde from the hot press to the cutting saw took place rather slowly. The local mean residence time at the cutting saw was clearly longer than the nominal time constant. Furthermore the time instant for maximum sulfur hexafluoride concentration occurred relatively late, 7 to $9 \mathrm{~min}$ after the sulfur hexafluoride injection. 
The local mean residence times measured at the roof exhaust fans varied only slightly, from 2.3 to $2.6 \mathrm{~min}$, in repeated tests. Compared to the nominal time constant of $7.8 \mathrm{~min}$, these residence times were notably shorter. The time instant for the maximum sulfur hexafluoride concentration occurred $1 \mathrm{~min}$ after the release of the compound at these sampling points. In addition, the standard deviation was smaller than for the other measurements. These results imply that the roof exhaust fans, $E_{1}$ and $E_{2}$, captured formaldehyde vapors, simulated with sulfur hexafluoride, very rapidly and efficiently. According to the results in table 2, all variables determined from the sulfur hexafluoride responses at fans $E_{1}$ and $E_{2}$ were similar. However, fan $\mathrm{E}_{1}$ was located noticeably closer to the site where sulfur hexafluoride was released than was fan $E_{2}$. Therefore, one would expect that fan $\mathrm{E}_{1}$ would have been more efficient than $\mathrm{E}_{2}$ in capturing tracer gas, as well as formaldehyde vapor. The measured formaldehyde concentrations at $E_{1}$ were many times higher than those of the tracer gas. There are two explanations for the discrepancy between the actual formaldehyde concentrations and the results of the tracer tests. First, the release of sulfur hexafluoride might not have correctly represented actual formaldehyde emissions. Second, the sulfur hexafluoride sampling was begun just after the release of the gas ended, obviously too late. A remarkable amount of tracer gas was captured by fan $E_{1}$ during the release period when no sampling was done. Therefore the values presented in table 2 obviously underestimate the performance of roof fan $E_{1}$.

More generally speaking, notable inaccuracies may occur when rapidly changing concentrations are estimated with the limited number of discrete samples. In practice, it is difficult to predetermine the proper sampling time and necessary number of samples for detecting concentration peaks and, on the other hand, for recording the concentration decay long enough to predict the slope.

The flow pattern of the fresh air supply was charted in the nitrous oxide experiments. The results of tests 7 and 8 in table 3 show that the new intake fan, $S_{2}$, distributed fresh air more efficiently in the workzone than in the upper part of the mill. Especially at the cutting saw, the fresh air supplied by fan $\mathrm{S}_{2}$ flushed the workzone very effectively, as can be seen from the values measured in the workzone and near the ceiling. The maximum concentration and the total dosage were clearly greater at $1.5 \mathrm{~m}$ than at $7.5 \mathrm{~m}$, whereas the local mean age of the supplied air and the time instants for the maximum concentration in the workzone were lower than the corresponding values measured at a height of $7.5 \mathrm{~m}$. The concentration of formaldehyde was stratified at the cutting saw. Near the ceiling the formaldehyde concentration was $1.5 \mathrm{ppm}$, while at a height of $1.5 \mathrm{~m}$ it was $0.8 \mathrm{ppm}$. This stratification was partly due to distribution of the fresh air supply and partly to the dispersion of the formaldehyde vapor from the hot press. The hood around the press was open in this direction, allowing the contaminant to spread.

The old supply air system, $S_{1}$, seemed to distribute air more efficiently towards the ceiling of the mill than within the workzone. This occurrence can be seen from the results of tests 9 through 11 (table 3 ), which showed that the mean age of the fresh air was younger at the height of 7.5 than at $1.5 \mathrm{~m}$. The maximum concentration and total dosage were also greater at 7.5 than at $1.5 \mathrm{~m}$. In the blending area, the concentration of formaldehyde in the workzone was even higher than that near the ceiling. This occurrence also indicates that the fresh air supply diluted formaldehyde vapors more efficiently in the zone near the ceiling of the blending area. The stronger diffusion of the air supplied through $S_{1}$ in the ceiling zone of the mill was due to the blowing direction of the supply jets and the buoyancy forces caused by the temperature of the fresh air, which was $4-5^{\circ} \mathrm{C}$ higher than that of the ambient air. The occurrence of fluctuations and short spikes, as shown in figure 4, was typical of the concentration response curves for tests 9 through 11 . These fluctuations, or spikes, made it difficult to determine accurately either the genuine maximum concentration of the response curve or the corresponding time instant.

To summarize, this study has shown that the tracer gas pulse method is applicable to charting the spread of contaminated air and the distribution of the fresh air supply in a complicated industrial environment. The approach is based on the age concept, the analysis of moments, and the determination of maximum concentration and the time instant of the maximum concentration of the pulse responses. The study nonetheless acknowledges that difficulties may occur in the simulation of contaminant release with tracer gas, if the source of contamination is wide and of complex geometry. Of the experimental techniques used, the continuous monitoring of the tracer concentration is preferable to discrete sampling.

\section{Acknowledgments}

My thanks are due to Mr S Aatola, Mr H Itkonen, Mr P Mäkelä, and Mr E Toppila for assisting with the field measurements.

\section{References}

1. American Conference of Governmental Industrial Hygienists, Committee on Industrial Ventilation. Industrial ventilation. 17th edition. Lansing, MI 1982.

2. Blesser BW. A systems approach to biomedicine. McGraw-Hill Book Company, New York, NY 1969.

3. Brandt S. Statistical and computational methods in data analysis. North-Holland Publishing Company, Amsterdam 1983.

4. Graupe D. Identification of systems. Van Nostrand Reinhold, New York, NY 1972.

5. Kauppinen T, Niemelä R. Occupational exposure to 
chemical agents in the particleboard industry. Scand $\mathbf{J}$ Work Environ Health 11 (1985) 257-363.

6. Lidwell OM. The evaluation of ventilation. J Hyg (Cambridge) 58 (1960) 297-305.

7. Malmström T-G, Ahlgren A. Aspects of ventilation in office rooms. Environ Int 8 (1982) 401-408.

8. Nauman EB. Residence time distributions and micromixing. Chem Eng Commun 8 (1981) 53-131.

9. Niemelä R, Toppila E, Rolin I. Characterization of supply air distribution in large industrial premises by the tracer gas technique. In: Goodfellow HD, ed. Ventilation '85. Elsevier Science Publishers, Amsterdam 1986, pp 797-804.

10. Niemelä R, Toppila E, Tossavainen A. The measurement of ventilation parameters by means of tracer gas techniques and a microcomputer. Ann Occup Hyg 28 (1984) 203-210.

11. Olander L. Karakterisering av lutftströmning och för- oreningsfördelning [Characterization of airflow patterns and contaminant distribution]. Presented at the congress ASF industriventilation 27-28 April 1983.

12. Sandberg $M$. What is ventilation efficiency. Build Environ 16 (1981) 123-135.

13. Sandberg M, Sjöberg $M$. The use of moments for assessing air quality in ventilated rooms. Build Environ 18 (1983) $181-197$.

14. Skåret E, Mathisen HM. Ventilation efficiency. Environ Int 8 (1983) 473-481.

15. Suomen standardoimisliitto. Työpaikan ilman formaldehydipitoisuuden määritys kromotrooppohappomenetelmällä [Determination of formaldehyde in workplace air using the chromotropic acid method]. Helsinki 1978. (SFS-standardi 3862).

Received for publication: 28 February 1986 